\title{
Resenha
}

\section{Desenvolvendo jovens leitoras ${ }^{1}$}

\author{
Geraldina Porto WITTER ${ }^{2}$
}

Marsha M. Sprague é doutora em educação pela University ofMiami e, há mais de 20 anos, atua naárea de leitura. Kara K. Keeling é doutora em inglês pela Indiana University e trabalha com literatura infanto-juvenil desde 1993. Ambas publicaram vários trabalhos na área. 0 livro aqui resenhado resulta de um trabalho realizado junto a jovens adolescentes que utilizou a literatura como forma de ensejar oportunidades para a discussão de seus problemas cotidianos, uma forma de biblioterapia pedagógica ou educacional. Explora-se principalmente o uso dos textos literários na busca da formação das garotas, não apenas como leitoras, mas como pessoas que precisam ser vistas em sua amplitude, considerando-se seu contexto de vida.

A estrutura do livro compreende prefácio, sete capítulos, epílogo, referências e índices de autores e de textos. No prefácio, as autoras abordam o surgimento e desenvolvimento de seu interesse pelos vários aspectos do tema e da organização do livro.

O primeiro capítulo enfoca as mudanças e dificuldades enfrentadas pelas jovens americanas. Como as autoras constataram, "a despeito de estudos e estatísticas indicando as dificuldades enfrentadas pelas jovens, poucas escolas adotaram programas enfocando as necessidades de desenvolvimento das jovens adolescentes" (p.17). O trabalho é justamente uma proposta de ação para suprir a lacuna observada em muitas escolas.
O capítulo seguinte trata do uso da literatura como forma de explorar as questões do desenvolvimento humano vivenciadas pelas jovens adolescentes. Para tanto, o primeiro passo é selecionar textos literários com personagens femininos na fase da adolescência que, direta ou indiretamente, vivenciem questões que preocupam as jovens.

É importante estabelecer uma estrutura para discussão, criando condições para que elas se expressem quanto aos problemas e sejam simultaneamente consideradas as expectativas da sociedade e das jovens. É relevante discutir o papel dos adultos, da aparência física, das colegas e das amigas.

O capítulo 3 apresenta as relações entre a literatura atual realista e os problemas que as jovens vivem na contemporaneidade. Entre os problemas enfocados, estão: a impossibilidade de se expressar livremente e o fato de ter que se conformar a padrões estabelecidos, a necessidade de ser popular, o álcool e as drogas, depressão, suicídio, automutilação, sexo, estupro, abuso físico, abuso sexual, gravidez precoce, distúrbios alimentares, família disfuncional e morte de pais. No final do capítulo, o leitor encontra um plano de aula em que é estabelecida a ligação entre o texto e a vivência de problemas pelas jovens.

No capítulo seguinte, romances baseados na História são enfocados como base para se considerar o velho e o novo em relação à problemática de ser uma jovem nos dias de hoje. Este tipo de obra permite às

1 Sprague, M. M. \& Keeling, K. K. (2007). Discovering their voices: engaging adolescent girls with young adult literature. Newark: IRA.

2 Unicastelo, Pró-Reitoria de Pós-Graduação. R. Carolina Fonseca, 584, 08230-230, Itaquera, SP, Brasil. 
adolescentes assumirem o papel de observadoras na análise das questões; basta lembrar a nítida divisão de gênero existente no passado em relação ao que ocorre atualmente. É destacada a importância de escolher obras em que as personagens femininas sejam plausíveis, incluindo as consideradas normais para a época histórica e as que escaparam de forma viável ao que era esperado naquela ocasião. O capítulo se fecha com um exemplo de plano de aula.

Em seguida, são consideradas personagens de mulheres fantásticas presentes tanto em obras de fantasia como nas de ficção científica. A estrutura básica é a mesma dos capítulos anteriores, mas as personagens apresentam características distintas que viabilizam enfocar outras questões, ou as mesmas questões vistas de outro ângulo - confrontando-se, assim, diferentes visões de mundo. Novamente o leitor tem um modelo de plano de aula como exemplo.

No capítulo 6 é retomado o Clube do Livro, amplamente discutido e pesquisado na literatura científica, mas apresentando base especialmente elaborada para o envolvimento de moças. Há uma breve história do Clube do Livro, de sua inserção no ambiente escolar e a criação da modalidade dedicada apenas a moças. As bases para atuar e os princípios subjacentes são os mesmos de qualquer Clube do Livro bem conduzido, apenas variam os critérios de escolha de textos e personagens para atender aos objetivos especiais de desenvolvimento e de discussão de problemas pelas moças que o frequentam.
O sétimo capítulo trata do uso de livros em atividades na sala de aula - por exemplo, quando um livro é lido pela classe para discutir a voz das jovens. Também é lembrado que os clubes literários podem ser valiosos no arranjo de situações para ajudar as jovens a se desenvolverem.

No epílogo, as autoras explicitam suas esperanças em relação às adolescentes que são atendidas na programação explicitada. Também afirmam que esperam que o livro possa ser útil a professores que pretendam usar as propostas nele contidas e que as apliquem também com rapazes, fazendo as devidas adaptações.

A bibliografia de apoio apresenta equilíbrio entre obras recentes e clássicas em relação ao período em que o assunto emergiu na literatura e passou esparsamente a ser cuidado em raras escolas.

Tema de grande atualidade é cuidar das diferenças de gênero no processo de ensino e aprendizagem, por isso, é de grande valia para professores interessados em ajudar adolescentes, sejam moças ou rapazes, pois o programa também pode ser aplicado aos últimos, desde que os personagens-alvo sejam do gênero masculino e que sejam tomados outros cuidados. O texto é útil para ser usado na formação de professores e em cursos de biblioterapia educacional, pedagogia, psicologia e psicopedagogia.

Recebido em: 30/5/2007 Aprovado em: 29/9/2008 